\title{
Analysis of different approaches to model the austempering heat treatment of ductile irons
}

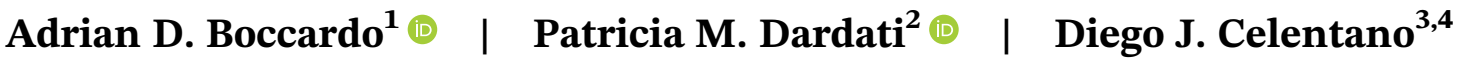

${ }^{1}$ Instituto de Estudios Avanzados en Ingeniería y Tecnología, IDIT, CONICETUniversidad Nacional de Córdoba, Córdoba, Argentina

${ }^{2}$ Grupo de Investigación y Desarrollo en Mecánica Aplicada, GIDMA, Facultad Regional Córdoba, Universidad Tecnológica Nacional, Córdoba, Argentina

${ }^{3}$ Departamento de Ingeniería Mecánica y Metalúrgica, Pontificia Universidad Católica de Chile, Santiago de Chile, Chile

${ }^{4}$ Centro de Investigación en

Nanotecnología y Materiales Avanzados (CIEN-UC), Pontificia Universidad

Católica de Chile, Santiago, Chile

\section{Correspondence}

Adrian D. Boccardo, Instituto de Estudios Avanzados en Ingeniería y Tecnología, IDIT, CONICET-Universidad Nacional de Córdoba, Vélez Sarsfield 1611, X5000

Córdoba, Argentina.

Email: aboccardo@frc.utn.edu.ar

\section{Funding information}

ANID-Chile, Grant/Award Number: FONDECYT 1180591; Universidad Tecnológica Nacional-Argentina, Grant/ Award Number: ASUTNCO0007785

\begin{abstract}
Austempered ductile iron is a metallic alloy of technological interest. Currently, the part design is added by means of simulations performed by using different types of models. This work aims at comparing three models respectively based on the Avrami's equation, spherical representative volume elements, and cellular automata; all of them are able to compute the phase evolutions during the ausferritic and martensitic transformations. The models are employed to reproduce the experimental heat treatments where their strongness and weakness are discussed.
\end{abstract}

\section{KEYWOR D S}

ausferritic transformation, austempered ductile iron, modeling assessment, numerical

simulation

\section{1 | INTRODUCTION}

Austempered ductile iron (ADI) is a metallic alloy that is commonly obtained by subjecting a ferritic/pearlitic ductile iron to a three-step austempering heat treatment. This process contains two isothermal stages developed at the austenitizing $\left(850^{\circ} \mathrm{C}<T_{\gamma}<950^{\circ} \mathrm{C}\right)$ and austempering temperatures $\left(250^{\circ} \mathrm{C}<T_{A}<450^{\circ} \mathrm{C}\right)$, being the last in which the ausferritic transformation takes place. ${ }^{1}$ During this transformation, the austenitic matrix transforms into ferrite that is grouped in sheaves as it is observed in Figure 1. The austempering time controls the amount of austenite consumed by ferrite, and when it is short enough, like $t_{1}$, a part of the austenite is transformed into martensite during the cooling down from $T_{A}$ to the environment temperature.

The ADI mechanical properties depend on its microstructure features obtained at the end of the heat treatment. ${ }^{2}$ The ADI microstructure is modified by the heat treatment variables such as the austenitizing and austempering temperatures, austempering time, among others, and the material characteristics such as the graphite nodule size, chemical 

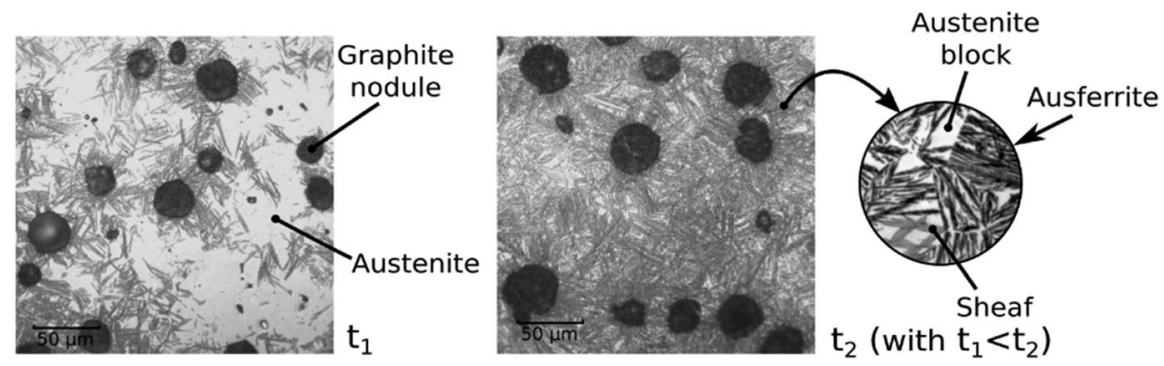

F I G URE 1 ADI microstructure for different austempering times

composition, and existence of alloying microsegregation. In order to aid the heat treatment design to obtain ADI parts with the required mechanical properties, it is possible to perform numerical simulations by employing different types of models to compute the final phase volume fractions at the environment temperature ${ }^{3,4}$ and the kinetics of phase change during the ausferritic transformation. ${ }^{2,5-10}$

The aim of this work is to compare three models that have been recently developed by considering different approaches to simulate the kinetics of phase change during the ausferritic transformation of ductile irons subjected to the austempering heat treatment.

\section{2 | MODELING}

The described models allow to simulate the phase evolution during the ausferritic and martensitic transformations by considering as starting point the microstructure (graphite and austenite) at $T_{\gamma}$. The symbols used throughout this work are defined in Table 1.

\section{1 | Ausferritic transformation model based on the Avrami's equation}

This model considers the nucleation and growth of ferrite platelets within the metallic matrix without distinguishing between nucleation on the nodule surface and nucleation at existing ferrite subunit tips. The ferrite platelet volume fraction, at time $t$, is computed by means of the Avrami's equation?

$$
f_{\alpha p}=f_{\alpha p_{\max }}\left[1-\exp \left(-k_{1} t^{k_{2}}\right)\right]
$$

The austenite film volume fraction is computed as $f_{\gamma f}=x_{\gamma f / \alpha p} f_{\alpha p}$, where $x_{\gamma f / \alpha p}=0.12$ as was proposed in GaudeFugarolas and Jacques, ${ }^{11}$ and the remaining austenite is considered as residual austenite. The carbon concentration is proposed uniform within the residual austenite, and it is determined by considering the carbon mass conservation during the transformation.

\section{2 | Ausferritic transformation model based on spherical representative volume elements}

In this model, the metallic matrix is proposed to be formed by ausferrite and austenite halos, as it is shown on the left side of Figure 2. The ausferrite, constituted by ferrite platelet, austenite film, and austenite block, evolves during the transformation due to the nucleation and growth of ferrite platelets at both graphite nodule surfaces and the existing ferrite subunit tips. The evolution of the ferrite platelet volume fraction is computed as follows by taking into account the size and amount of graphite nodules ${ }^{8}$ :

$$
f_{\alpha p}=\frac{4 \pi}{3} \sum_{i=1}^{n s e t s g} f_{\alpha p n_{i}} N_{\text {set }_{i}} r_{\gamma_{i}}^{3},
$$


T A B L E 1 Nomenclature

\section{Symbols}

$c_{\gamma b}$ : Austenite block carbon concentration

$\boldsymbol{D}_{\gamma}$ : Isotropic carbon diffusion second-rank tensor
$N_{\alpha p s}^{e x t}$ : Number of nucleated subunits into ausferrite halo

$n c$ : Total number of cells employed to discretize the volume element of AMCA model

$n c_{s h}:$ Number of cells with sheaf state

$\Delta G m$ : Maximum free energy available for paraequilibrium nucleation

$f_{a b}$ : Function to consider the effect of austenite block carbon $\quad N_{\text {set }}$ : Number of graphite nodules per unit of volume concentration on $\Delta G m$

$f_{\alpha p}:$ Ferrite platelet volume fraction

nsetsg : Set number of equal size graphite nodules

$\boldsymbol{f}_{\boldsymbol{\alpha p _ { \text { max } }}}$ : Maximum ferrite platelet volume fraction obtained when the ausferritic transformation stops

$f_{\alpha p n}$ : Ferrite volume fraction with respect to $v_{R V E}$

$R$ : Universal gas constant

$r_{\gamma}$ : Radius of the representative volume element

$\dot{r}_{s h}$ : Radius growth rate of a sheaf

$f_{\gamma}:$ Austenite volume fraction

$t:$ Time

$f_{\gamma f}:$ Austenite film volume fraction

$T_{A}$ : Austempering temperature

$f_{\gamma r}$ : Retained austenite volume fraction at the environment temperature

$f_{\gamma r \text { (end) }}: f_{\gamma r}$ when the ausferritic transformation stops

$f_{\text {sh }}$ : Sheaf volume fraction

$t_{\alpha p}$ : Temperature-dependent thickness of a ferrite platelet

$T_{\gamma}$ : Austenitizing temperature

$t_{\gamma f}$ : Temperature-dependent thickness of an austenite film

Gn : Minimum energy necessary to obtain a detectable amount of ferrite

$h$ : Planck constant

$T_{\text {env }}$ : Environment temperature

$k_{i=1,2}:$ Constants of the Avrami's equation

$t_{\text {inc }}:$ Ferrite platelet incubation time

$k_{a}$ : Constant of the ferrite platelet incubation time equation

$k_{b}$ : Boltzmann constant

$k_{m}$ : Constant of martensitic transformation model

$T_{M S}:$ Martensite start temperature

$u_{\alpha p}$ : Temperature-dependent ferrite subunit volume

$v o l_{R V E}:$ Volume of the representative volume element

$x_{\gamma f / \alpha p}:$ Ferrite platelet-austenite film volume relation

$\xi$ : Coefficient that accounts the reduction of nucleation sites during the evolution of the ausferritic transformation
F I G U RE 2 ADI microstructure representation according to AMSE and AMCA models

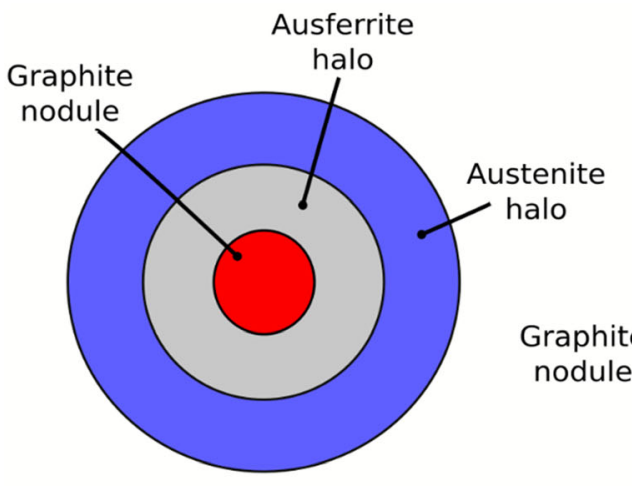

AMSE

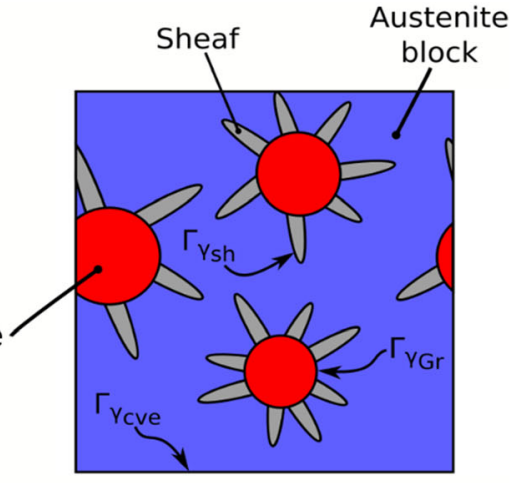

AMCA

where $i$ identifies the set of equal size graphite nodules.

The volume fraction $f_{\alpha p n_{i}}$ is computed by solving the differential equation $d f_{\alpha p n_{i}} / d t=\left(1-\xi_{i}\right) u_{\alpha p} N_{\alpha p s_{i}}^{e x t} /\left(\operatorname{vol}_{R V E_{i}} t_{i n c_{i}}\right)$ using the Euler's method. The incubation time is computed with the equation $t_{i n c_{i}}=k_{a} /\left[\left(k_{b} T_{A} / h\right) \tanh \left(-\frac{\Delta G m_{i}-G n}{R T_{A}}\right)\right]$ proposed in Gaude-Fugarolas and Jacques. ${ }^{11}$ The maximum free energy is computed during the transformation as $\Delta G m_{i}=\Delta G m^{o}-f_{a b_{i}}\left(\Delta G m^{o}-G n\right)$, where $\Delta G m^{o}$ is the maximum free energy at the beginning of the transformation and 
the function varies in the range $0 \leq f_{a b_{i}} \leq 1$. The austenite block carbon concentration is proposed uniform and it is computed by considering the carbon mass conservation during the transformation.

\section{3 | Ausferritic transformation model based on cellular automata}

This model employs a cubic volume element with periodic boundaries, which is discretized by means of cells that have three possible states (graphite nodule, sheaf, and austenite block) in order to represent the ADI microstructure during the ausferritic transformation. ${ }^{9}$ At the beginning of the transformation, the microstructure is formed by graphite nodules modeled as spheres randomly distributed into a metallic matrix that is formed by austenite with alloying element microsegregation. The phase transformation starts with the growth of sheaves on the graphite nodule surfaces, as it is shown on the right side of Figure 2, and it continues by consuming the austenite block. Considering that sheaves are formed by a fixed ratio of ferrite platelets and austenite films, the ferrite platelet volume fraction is computed as ${ }^{10}$

$$
f_{\alpha p}=\frac{f_{s h}}{\left(1+x_{\gamma f / \alpha p}\right)},
$$

where the sheaf volume fraction is computed as $f_{\text {sh }}=n c_{s h} / n c$.

Each sheaf has the shape of a bipyramid whose length and radius evolve during the transformation with $\dot{l}_{s h}=l_{\alpha p} / t_{i n c}$ and $\dot{r}_{s h}=\left(t_{\alpha p}+t_{\gamma f}\right) / t_{i n c}$ growth rates, respectively. The incubation time is determined with the equation proposed in Gaude-Fugarolas and Jacques ${ }^{11}$ whose free energy $\Delta G m$ is computed by taking into account the chemical composition of the austenite block cell. The austenite block carbon concentration is computed during the process by solving the Fick's second law $\partial c_{\gamma b} / \partial t=\operatorname{div}\left[\boldsymbol{D}_{\gamma} \operatorname{grad}\left(c_{\gamma b}\right)\right]$ using the finite difference method. The applied boundary conditions are periodic at the cubic volume element boundary $\left(\Gamma_{\gamma_{c v e}}\right)$ and, in addition, the carbon flux equal to zero at both austenite block-graphite $\left(\Gamma_{\gamma_{G r}}\right)$ and austenite block-sheaf $\left(\Gamma_{\gamma_{s h}}\right)$ boundaries, see right side of Figure 2 . The evolution of the sheaves along the volume element is performed by a capture algorithm that considers the available sites for the ferrite platelet nucleation.

\section{4 | Martensitic transformation model}

After the cooling down from $T_{A}$ to $T_{e n v}$, a part of the austenite is retained and the other is transformed into martensite. The relation between retained austenite and martensite volume fractions depends on the kinetics of phase change during the ausferritic transformation, austempering time, and martensite start temperature.

For the previously presented three ausferritic models, the volume fraction of retained austenite at the environment

temperature is computed as $f_{\gamma r_{j}}=f_{\gamma_{j}}\left(1-f_{\gamma_{j} m}\right)$, where $f_{\gamma_{j} m}$ is computed with $\ln \left(1-f_{\gamma_{j} m}\right) / f_{\gamma_{j} m}=-1-k_{m}\left(T_{M S_{j}}-T_{\text {env }}\right) .{ }^{12}$ The $T_{M S_{j}}$ is determined by the chemical composition-dependent equation presented in. ${ }^{13}$ The variable $j$ indicates the austenite region able to be transformed into martensite $(j=$ residual for AMA, $j=$ block and halo for AMSE, and $j=$ block for AMCA).

\section{3 | RESULTS AND DISCUSSION}

The presented models are employed to simulate the heat treatment of ductile irons with different chemical compositions. The constants $k_{i}=1,2, a, m$ were fitted by using the normalized retained austenite volume fraction measured from experiments reported $\mathrm{in}^{14,15}$ for ductile irons with the properties shown in Table 2. The heat treatments were developed at $T_{\gamma}=870^{\circ} \mathrm{C}$ and $T_{A}=375^{\circ} \mathrm{C},{ }^{14}$ and $T_{\gamma}=900^{\circ} \mathrm{C}$ and $T_{A}=370^{\circ} \mathrm{C} .{ }^{15}$ Because both ausferritic and martensitic transformations consume austenite, the constants were obtained as follows. At first, the constant $k_{m}$ was determined at a short austempering time due to the ausferritic transformation produces a very small ferrite platelet volume fraction. Then, the constants $k_{i}=1,2, a$ were computed by fitting the simulated evolution of retained austenite volume fraction to the 
T A B L E 2 Nominal chemical composition in wt\% and nodule count in $\mathrm{nod} / \mathrm{mm}^{2}$ of the analyzed ductile irons

\begin{tabular}{llllllll} 
Ductile Iron & $\mathbf{C}$ & $\mathbf{S i}$ & $\mathbf{M n}$ & $\mathbf{C u}$ & $\mathbf{N i}$ & $\mathbf{M o}$ & Nodule Count \\
\hline 1 & 3.39 & 2.56 & 0.37 & 0.29 & - & 0.25 & 104 \\
\hline 2 & 3.52 & 2.64 & 0.67 & 0.25 & - & 0.25 & 102 \\
\hline 3 & 3.5 & 2.32 & 0.59 & 0.29 & - & 0.33 & 230 \\
\hline 4 & 3.8 & 2.77 & 0.04 & 0.33 & 0.07 & - & 180 \\
\hline 5 & 3.6 & 2.8 & 0.02 & 0.9 & 1.02 & - & 66 \\
\hline
\end{tabular}

experimental data for different values of the austempering time. The constant $k_{a}$ was determined by using the AMCA model because it predicts a smooth evolution of the retained austenite volume fraction with the austempering time, as it is observed in the experiments, which facilitates the fitting process.

The obtained constant values are shown in Table 3. Since the AMA constants $k_{i=1,2}$ depend on the graphite nodule size, chemical composition, and austenitizing and austempering temperatures, they had to be adjusted for each analyzed ductile iron. Because the graphite nodule size is explicitly considered by the volume elements and the chemical composition, austenitizing temperature, and austempering temperature modify $\Delta G m$ and $G n$ energies, the AMSE and AMCA models required only one $k_{a}$ to fit the analyzed cases.

The influence of the austempering time on the ferrite platelet fraction, retained austenite fraction, martensite fraction, and austenite carbon concentration at environment temperature is presented in Figure 3 for the ductile iron 1 . The same behavior was observed for ductile irons $2-5$. The simulations were performed by considering all graphite nodules of equal

TA B LE 3 Constant values for the analyzed ductile irons

\begin{tabular}{lllll} 
Ductile Iron & $\mathbf{K}_{\mathbf{1}}$ & $\mathbf{K}_{\mathbf{2}}$ & $\mathbf{k}_{\mathbf{a}}$ & $\mathbf{k}_{\mathbf{m}}$ \\
\hline 1 & $7.679 \times 10^{-3}$ & 0.902 & $1.301 \times 10^{14}$ & $6.6 \times 10^{-3}$ \\
\hline 2 & $6.796 \times 10^{-3}$ & 0.872 & & \\
\hline 3 & $2.594 \times 10^{-2}$ & 0.679 & & \\
\hline 4 & $1.226 \times 10^{-2}$ & 0.797 & & \\
\hline 5 & $6.314 \times 10^{-3}$ & 0.784 & & \\
\hline
\end{tabular}

F I G U RE 3 Phase volume fractions and mean austenite carbon concentration for ductile iron 1
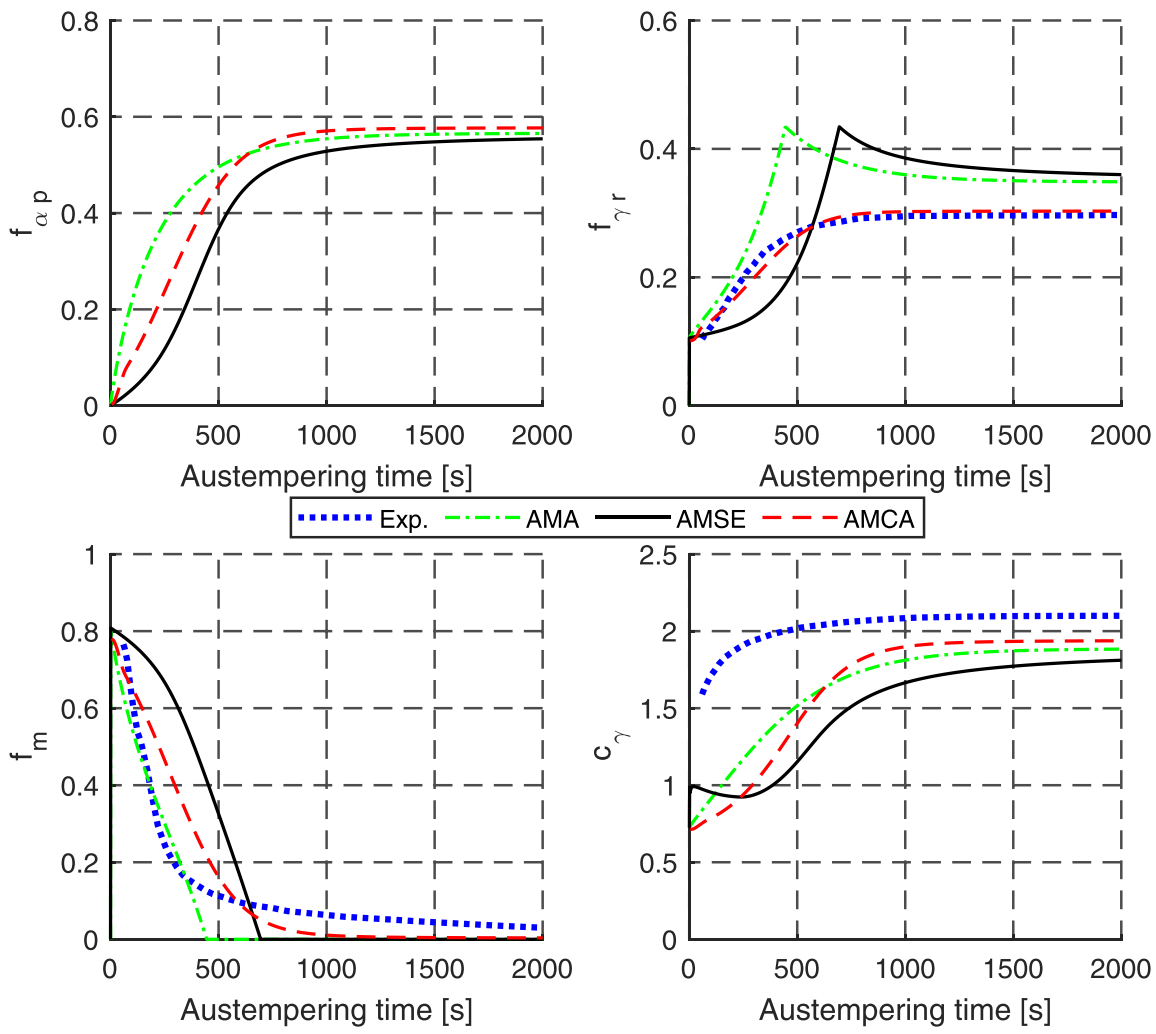
size (nsetsg = 1) for the AMSE model, and six graphite nodules of equal size randomly distributed within the cubic volume element and austenite with microsegregated distribution of alloying elements for the AMCA model. Moreover, the number of cells employed to discretize the cubic volume element of the AMCA model, $80 \times 80 \times 80$ cells, was determined by means of a convergence study of the model results. The AMA and AMSE models required less than 1 min to simulate each case but the AMCA model required around $40 \mathrm{~h}$ of CPU time using the same computational facilities.

The increment of the austempering time increases the ferrite platelet volume fraction allowing the austenite carbon enrichment by carbon rejection from ferrite to austenite. When the transformation stops, the predicted ferrite platelet volume fractions are similar but their evolutions are different. This occurs, for the AMSE and AMCA models, due to the different simplifications adopted with regard to the microstructure geometry, nucleation site, and carbon distribution. The decrement of martensite volume fraction occurs because there is less austenite with high carbon concentration when the ausferritic transformation is in an advanced state. Only the AMCA model is able to predict a small martensite volume fraction (0.01) at the last to freeze region when the ausferritic transformation stops because it considers the presence of alloying element microsegregation. The AMA and AMSE models do not capture correctly the influence of the austempering time on the retained austenite fraction. When the martensitic transformation does not occur at $T_{e n v}$, the evolutions of retained austenite fraction present a peak at austempering time $442 \mathrm{~s}$ for AMA model and $694 \mathrm{~s}$ for AMSE model. These peaks appear due to the simplifications in the austenite carbon concentrations and they do not disappear when the constants $k_{i=1,2, a}$ are modified, complicating the fitting process. The AMCA model is able to fit correctly the retained austenite volume fraction experimentally measured showing the remarkable improvement obtained by computing the austenite carbon concentration by means of the diffusion model. In all cases, the simulated mean austenite carbon concentration is lower than the observed in the experiments at a short austempering time because the austenite film with high carbon concentration was not included in the average calculation. Moreover, only the AMCA model is able to predict the presence of austenite with high carbon concentration around the sheaves at a short austempering time.

The influence of graphite nodule count on the required time to obtain a total retained austenite volume fraction of $0.9 f_{\gamma r(\text { end })}$ for the AMCA model and $1.1 f_{\gamma r(\text { end })}$ for the AMA and AMSE models is presented in Figure 4. It is observed that the increment of nodule count, or decrement of the graphite nodule size, decreases the mentioned required time. This behavior is expected because the ferrite platelet nucleation on the graphite nodule surfaces increases with the increment of the nodule surface-matrix volume ratio, taking this nucleation a key role during the phase transformation. The difference between the AMSE and AMCA results, generated by the reasons mentioned above, could be minimized by reducing the constant $k_{a}$ to $40 \%$ for the AMSE model. On the other hand, better performance for the AMA model was expected, but the predicted retained austenite behavior hinders the correctness of the parameter calibrations for different values of the austempering time.

The austempering heat treatment of real pieces with nonhomogeneous chemical composition and microstructure features could be simulated by computing the phase evolutions with the AMA, AMSE, or AMCA models at some points of the part. The AMA and AMSE models were employed in thermomechanical-metallurgical formulations to predict the phase transformations and temperature and stress evolutions during the heating up and cooling down of the threestep austempering heat treatment of complex parts. ${ }^{7,16}$ Currently, the implementation of the AMCA model in the

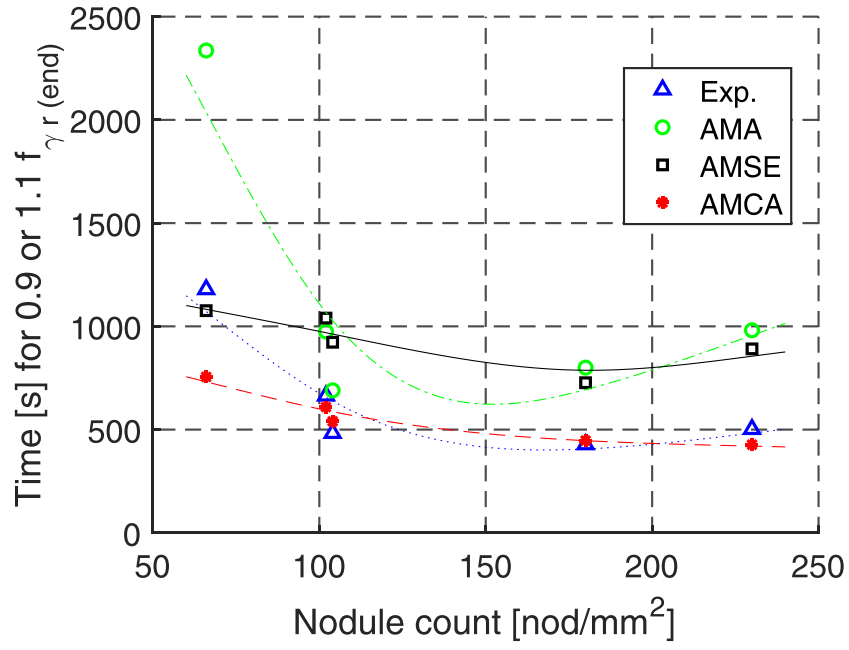

FI G URE 4 Required time to obtain $0.9 f_{\gamma r(\text { end })}$ or $1.1 f_{\gamma r(\text { end })}$ for ductile irons $1-5$ 
mentioned formulations is limited by the high computational cost required to compute the phase evolutions during the ausferritic transformation at hundreds of piece points. Alternatively, the carbon distribution into austenite and the influence of the alloying microsegregation predicted by the AMCA model could be employed to propose different modifications of the AMSE model to improve its performance keeping a low computational cost.

\section{4 | CONCLUSIONS}

This work compares different approaches to model the phase evolutions of ductile irons during the ausferritic transformation. The main conclusions are the following:

- Using retained austenite volume fractions measured from experiments is not the best option to fit the constants when the predictions present peaks in the retained austenite volume fraction as occur in AMA and AMSE models.

- Considering carbon diffusion into austenite (AMCA model) allows to predict correctly the retained austenite behavior observed in the experiments.

- The AMCA model has a better performance than models AMA and AMSE, but it requires high computational cost which is a disadvantage particularly in the simulation of complex parts. Analyzing the AMCA results, as carbon diffusion and alloying microsegregation, different modifications could be implemented into the AMSE model to improve its performance keeping a low computational cost.

\section{ORCID}

Adrian D. Boccardo (1) https://orcid.org/0000-0003-3299-2510

Patricia M. Dardati (1D https://orcid.org/0000-0002-3294-2962

\section{REFERENCES}

1. Fraś E, Górny M, Tyrała E, Lopez H. Effect of nodule count on austenitising and austempering kinetics of ductile iron castings and mechanical properties of thin walled iron castings. Mater Sci Technol. 2012;28(12):1391-1396.

2. Thomson RC, James JS, Putman DC. Modelling microstructural evolution and mechanical properties of austempered ductile iron. Mater Sci Technol. 2000;16(11-12):1412-1419.

3. Yescas MA, Bhadeshia HKDH, MacKay DJ. Estimation of the amount of retained austenite in austempered ductile irons using neural networks. Mater Sci Eng a. 2001;A311:162-173.

4. Yescas MA, Bhadeshia HKDH. Model for the maximum fraction of retained austenite in austempered ductile cast iron. Mater Sci Eng a. 2002;A333:60-66.

5. Yoo SM, Moeinipour K, Ludwig A, Sahm PR. Numerical simulation and experimental results of in situ heat treated austempered ductile iron. Int J Cast Met Res. 1999;11(6):483-488.

6. Kapturkiewicz W, Burbelko AA, Lelito J, Fraś E. Modelling of ausferrite growth in ADI. Int J Cast Met Res. 2003;16(1-3):287-292.

7. Boccardo AD, Dardati PM, Celentano DJ, Godoy LA, Górny M, Tyrała E. Numerical simulation of austempering heat treatment of a ductile cast iron. Mater Trans B. 2016;47B:566-575.

8. Boccardo AD, Dardati PM, Celentano DJ, Godoy LA. A microscale model for ausferritic transformation of austempered ductile irons. Mater Trans A. 2017;48A:524-535.

9. Boccardo AD, Dardati PM, Godoy LA. Influence of alloy element distributions on austempered ductile irons. Mater Sci Technol. 2018;34 (17):2153-2165.

10. Boccardo AD, Dardati PM, Godoy LA. A cellular automaton-finite difference simulation of the ausferritic transformation in ductile iron. Mater Sci Technol. 2018;34(14):1710-1722.

11. Gaude-Fugarolas D, Jacques PJ. A new physical model for the kinetics of the bainite transformation. ISIJ Int. 2006;46(5):712-717.

12. Khan SA, Bhadeshia HKDH. Kinetics of martensite transformation in partially bainitic 300M steel. Mater Sci Eng a. 1990;129(2):257-272.

13. Nehrenberg AE. Technical publication 2059: discussion, iron and steel division. Met Technol (N Y). 1946;XIII:33-43.

14. Liu J, Elliott R. The influence of cast structure on the austempering of ductile iron, part 3: the role of nodule count on the kinetics, microstructure and mechanical properties of austempered Mn alloyed ductile iron. Int J Cast Met Res. 1999;12(3):189-195.

15. Darwish N, Elliott R. Austempering of low manganese ductile irons. Mater Sci Technol. 1993;9(7):572-585.

16. Boccardo AD, Dardati PM, Celentano DJ, Godoy LA. Austempering heat treatment of ductile iron: computational simulation and experimental validation. Finite Elem Anal des. 2017;134:82-91.

How to cite this article: Boccardo AD, Dardati PM, Celentano DJ. Analysis of different approaches to model the austempering heat treatment of ductile irons. Mat Design Process Comm. 2020;e208. https://doi.org/10.1002/ $\underline{\text { mdp2.208 }}$ 